\title{
Muayak Oral Literature in Ogan Komering Ulu Selatan Province; Position, Function and Vitality Analysis
}

\author{
Hetilaniar $^{1 *}$, Frenky Daromes Ardesya ${ }^{2}$
}

\author{
${ }^{1}$ Universitas PGRI Palembang \\ ${ }^{2}$ Balai Bahasa Provinsi Sumatera Selatan \\ *Corresponding Author.Email: hetilaniar@univpgri-palembang.ac.id
}

\begin{abstract}
Muayak oral literature is an old form of poetry in the form of rhymes sung in groups of 6-8 people. Muayak serves as a means of conveying messages through the media of rhymes, songs, and dances. Muayak has at least three important functions in the Ranau people: welcome guests of honor, weddings, and entertainment facilities. Based on the data analysis results, the vitality of Muayak in Ogan Komering Ulu Selatan (OKUS), especially in the Buay Pematang Ribu Ranau Tengah is still in the same category with a total average index of 0.90 . Two categories that are still stable but need to be maintained/cared for are the category of the number of speakers and the community population and muayak learning in schools.
\end{abstract}

Keywords: Muayak, Position and Function, Literary Vitality

\section{INTRODUCTION}

South Sumatra and all regions in the archipelago are rich in oral literature or regional literature. However, in reality, there is not much oral or regional literature known to the Indonesian people, especially the younger generation (millennials), because they are more familiar with the virtual world. This is related to the condition of oral literature, which is vulnerable to extinction. Even if it is not extinct, its existence is far from being popular or not well known. The main cause of the extinction of unpopularity is the lack of documentation in records or writing. Therefore, activities related to the preservation of oral literature must be carried out. One form of this conservation effort is literary research. Through a study, it will be possible to determine the state of literature in the area. This research on muayak literature is expected to provide information related to muayak in Ogan Komering Ulu Selatan Province, especially the Ranau clan, about how the position and function of muayak develop in their area. This is necessary so that the community's sense of belonging to this regional literature can continue to be developed.

Along with the times and challenges in globalization's current era, local wisdom like this may be eroded and abandoned. By conducting research related to the existence of oral literature, including the vitality of oral literature, it is hoped that the survival power to survive and develop can occur. Literary vitality is very important because oral literature is a unique and high-value cultural property.

The obligation to protect oral literature or regional literature is stipulated in Law Number 24 of 2009 concerning the Flag, Language, and Symbol of the State and the National Anthem. Especially for the protection of oral or regional literature, it is stated in article 42 . The following paragraph 1 contains the protection of regional literature.

Local governments are obliged to develop, foster, and protect regional languages and literature so that they continue to fulfill their position and function in social life according to the times and so 
that they remain part of Indonesia's cultural wealth. [1].

Research on the position, function, and vitality of oral or regional literature focuses on oral literary works that have an inheritance system and are supported by a particular community or group of people. In this research, what is meant is the people in Ogan Komering Ulu Selatan Province, South Sumatra. The locus of this research, namely: Gunung Raya Village, Warkuk Ranau Selatan Province, and Sukajaya Village. This research locus is known that several oral literature or regions are still well known, including Muayak, Rejung, and Talibun. The research problem's formulation is the position, function, and vitality of Muayak oral literature in Ogan Komering Ulu Selatan Province, South Sumatra? This research aims to describe the position and function and determine the vitality of Muayak oral literature in Ogan Komering Ulu Selatan Regency, especially in the research locus, the border area with West Lampung Province. Describe Muayak oral literature's role as a symbol of community identity in Gunung Raya village, Warkuk Ranau Selatan sub-Province, and Sukajaya village, Ogan Komering Ulu Selatan Province in the border area with West Lampung Province. This research uses the theory of vitality in general and specifically. Also, the theory of oral literature or areas becomes binding for arriving at oral literature at the research locus. The concept of vitality based on the Fourth Edition of KBBI is the ability to survive; life force [3]. Furthermore, the team that compiled the Technical Guidelines for the Implementation of Language and Literature Conservation stated that vitality is the vitality of a language and literature that refers to its intensity and existence in various social contexts for specific purposes [4]. Thus, it can be understood that literary vitality is the life force or ability to survive or survive oral or regional literary works, which refer to their intensity and existence in various social contexts for specific purposes.

Literature or literature expresses human thoughts and feelings, both oral and written (printed), using beautiful language according to the context [5]. Forms and forms of oral literature can be in the form of poetry, short stories, novels, fairy tales, proverbs, etc. All of this continues to change and develop according to the times which are also influenced by technology and cultural changes. This is consistent with Damono's statement, which states that cultural and technological changes will inevitably affect these methods [6]. Various concepts about regional literature from various sources can be seen in the following description. Regional literature in the context of literature in Indonesia is a regional cultural wealth whose life is very dependent on the supporters of the relevant regional culture [7].

Furthermore, it is said that regional literature is creative work that contains thoughts, experiences, and appreciation of life that are expressed aesthetically in regional languages, critical reviews of literary works in regional languages, or critical reviews of regional literary works [8]. In the Guidelines for the Extension of Indonesian Literature, oral literature is a product of traditional society, so that it can be called traditional literature [9]. Furthermore, according to Atmazaki, oral literature is conveyed orally from the mouth of a storyteller or poet to a person or group of listeners [10]. Endraswara states that oral literature is a work that has been transmitted from mouth to mouth from generation to generation [11].

Based on these various opinions, oral literature is a literary work type with a peculiarity that spreads in traditional societies, depicts community life that contains values, and is conveyed directly. This statement is by Hutomo in Sudikan stating that oral literature includes literary expressions of the citizens of a culture that is spread and passed down from generation to generation orally (word of mouth) [12].

Regarding the vitality of Muayak's oral literature, the data taken must pay attention to certain factors. There are eight determinants of the vitality of oral literature. The eight factors, namely: inheritance among the younger generation, the proportion of speakers of oral literature in the population, transition of the realm of oral literature, transfer of oral literature, oral literature in learning in schools, the government's attitude towards oral literature, people's attitudes towards oral literature, and the amount and quality of documentation [13].

Furthermore, it is explained that the eight groups of factors can be divided into four groups, namely (1) the level of danger (indicated by factors a e), (2) the attitudes and policies of stakeholders (indicated by factor f), (3) the attitude of the owner community, oral literature (g-factor), and (4) the urgency of documentation (h-factor). Determination of 
oral literature that will be used as the object of research material is carried out by conducting a kind of clustered group discussion (FGD / FGD) simply. With DKT? The FGD will find out which oral literature is the most popular in the research locus. Based on the proposal made by the coordinator of the 2019 Language and Literature Vitality Research team, the FGD should pay attention to the following components.

1. The number of participants is 80 people.

2. Facilitators: three people (researchers) from the South Sumatra Language Center).

3. Procession: Explanation of the objectives and target results by the facilitator; Determining some of the best known oral literature in the stack; Division of groups based on the number of selected oral literature (optional); Discussion of the advantages of oral literature choice group (optional); Presentation of discussion results (optional); Determination of superior oral literature; Filling out the questionnaire together; the data collection team collects the results; and Closing.

The respondents needed in this study must meet the criteria or must have individual characteristics. The following are the characteristics of the respondents compiled by Susilastri.

1. Gender consists of males and females.

2. The age group of the respondents at the time of the study is measured in units of years. Data to be obtained is categorized as early adulthood ( $<25$ years), middle adulthood ( $>25-50$ years), and late adulthood (50 years).

3. Place of birth is the area of birth of the respondent, whether inside the hamlet or outside the hamlet).

4. However, ethnicity refers to the term ethnicity, whether it is heterogeneous and homogeneous.

5. Education level is the education level of the respondent (low, middle, and high)

6. Type of work, namely the type of source of livelihood of the respondent (low, medium, and high).

7. Length of stay/domicile is when the respondent resides in a hamlet or village with age $<25$ years, 25-50 years, and $>50$ years.

8. Residence/domicile is the location where the respondent resides in a hamlet or village.

9. Mother tongue name is the designation for the respondent's mother tongue.
10. The area of use for the mother tongue is the area where the mother tongue is spoken.

The index is the ratio between two certain linguistic elements that may measure a certain characteristic [13].

\section{METHODS}

This research is qualitative-quantitative. With a qualitative approach, the data can be obtained by interviewing, observing, and filling out a questionnaire. Quantitative calculations are carried out to determine the percentage of answers from respondents using SPSS. The sample selection used the purposive sampling technique.

The informant or respondent in this study is a person who is asked to provide information or is asked for information directly through interviews [3]. In this study, respondents were also asked to fill out the instruments prepared. The data collection was carried out for five days, starting on March 20-24, 2019. The data was taken in several places: Gunung Raya Village, Pagar Dewa Village, and Sukajaya Village, directly adjacent to West Lampung Province.

\section{RESULTS AND DISCUSSION}

\subsection{Overview of Ogan Komering Ulu Selatan Province}

Geographically, Ogan Komering Ulu Selatan Province is located between 103022-104021 East Longitude and between 04014-04055 South Latitude. It has an area of $5,849.89 \mathrm{~km} 2$ or 549,394 ha. The South Ogan Komering Ulu Regency boundaries are: In the north, it is bordered by Ulu Ogan Province, Pengandonan Province, and Lengkiti Province, Ogan Komering Ulu Province. In the south, it is bordered by West Lampung Province, and West Coast of Lampung Province, and Kaur Regency, Bengkulu Province. The west is bordered by Bengkulu Selatan Regency, Bengkulu Province, and Muara Enim Regency. The East side is bordered by Ogan Komering Ulu Timur Province and Way Kanan Regency, Lampung Province. 


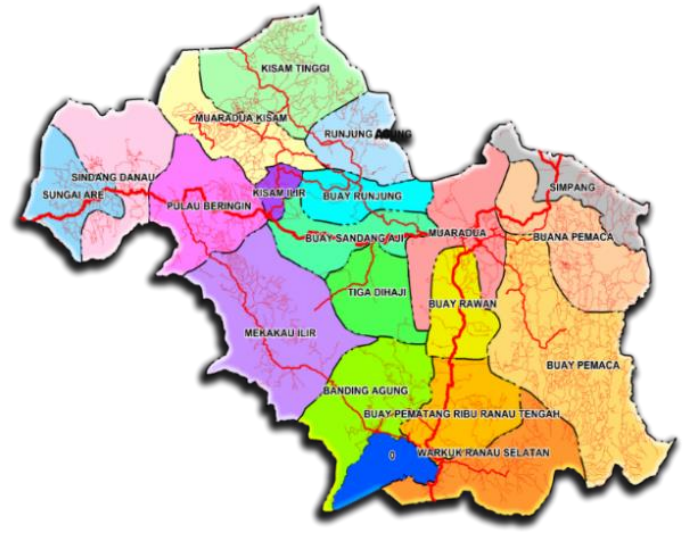

Image 1.

Map of South Ogan Komering Ulu Province (OKUS)

One of the popular oral literature in Ogan Komering Ulu Selatan Province is Muayak. Muayak is known to many people in Ogan Komering Ulu Selatan Province. Muayak or wayak originates from an old hamlet in Ogan Komering Ulu Selatan Province, namely Jepara Village, which Marga Ranau as the center of cultural development and influencing the surrounding areas including in the area which is the locus of this research. The area in question is Sukajaya Village, South Warkuk Ranau Province, directly adjacent to West Lampung Province. Based on information from the Secretary of the Province Head of Warkuk Ranau Selatan Province, more than $90 \%$ speak Ranau. The rest is in Indonesian, Javanese, and others. Thus, the oral literature of Muayak that develops in society is also spoken in the Ranau language.

The administrative division of Warkuk Ranau Selatan Province consists of 16 villages as follows: Kota Batu, SUkajaya, Pagardewa, Tanjung teak, Gunungaji, Gunungraya, Pilla, Remanamjaya, Bedengtiga, Kiwisraya, Segigokraya, Bumiagung, Mekarsari, Gedungdanau, Tanjungbaru, and Waywangi.

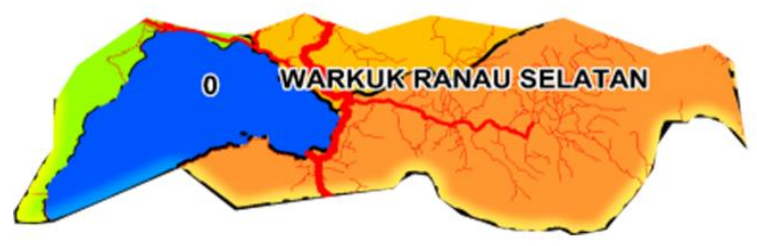

Image 2. Map of South Warkuk Ranau Province

Based on Warkuk Ranau Tengah Province's statistical data, the population of Central Warkuk Ranau Province is 24,875 , consisting of 12,885 men and 11,990 women. The majority of the population in this sub-Province is Muslim. Community occupations are dominated by farmers $(10,385)$ and entrepreneurs (1095). The rest varies, including ASN in government, ASN for teachers, honorary teachers, paramedics, retirees, laborers, fishermen, traders and TNI, and POLRI.

\subsection{The Results of Muayak Analysis in Ogan Komering Ulu Selatan Province (OKUS)}

Muayak is an old form of poetry in the form of poetry sung in groups, at least 6-10 people and usually accompanied by $\mathrm{T}$ Terbang, Gambus, to a single organ (currently). Muayak has a Sujak or style that is different between men and women. Women's styles developed more varied than women's styles, as well as various forms of dance. Muayak serves as a means of conveying messages through the media of rhymes, songs, and dances. Muayak has at least three important functions in the Ranau community, namely; (1) To welcome the guest of honor, the muayak that is said when welcoming this guest of honor aims to respect the guest and is often used as a means of conveying messages implicitly through the spoken poems (2) weddings, wayak in a wedding ceremony usually contains speeches in the form of advice, life journeys, to humorous rhymes, and (3) entertainment facilities, the wayak that is spoken usually contains humorous rhymes and rhymes for young people whose main purpose is more a means to entertain people/places they belong to. 
Fifty-nine questions and statements are provided, divided into 9 groups to find out the vitality of oral literature in Ogan Komering Ulu Selatan Province, especially in Warkuk Ranau Tengah District. The nine groups were developed from the factors of literary vitality plus one group of respondent identities. Group I about the identity of the respondent with 11 questions. Group II regarding inheritance among the younger generation, as many as six statements. Group III about the proportion of Muayak speakers in the population as many as six statements. Group IV regarding the transition of the Muayak realm consisted of six statements. Group V about the transfer of Muayak rides as many as six statements. Group VI about Muayak in learning in school as many as six statements. Group VII regarding the government's attitude towards Muayak consisted of six statements. Group VIII on community attitudes towards Muayak. Group IX regarding the amount and quality of documentation.

Data in the form of answers and responses from respondents are then tabulated and processed statistically using SPSS. The following shows the results of data processing in the form of a description of the respondents' composition, a description of the frequency of respondents' responses to statement items, and Muayak's oral literature's vitality.

\subsubsection{Descriptions of Respondents' Composition a. Description of Respondent Composition}

The description of the composition of respondents based on gender consisted of 46 males and 34 females. Respondents aged less than 25 years, 29 people, 25-50 years 45 people, and over 50 years 6 people. 15 respondents were not married, and 65 people were married-respondents who have the same ethnic partner as many as 26 people. The education level consists of 22 elementary school students, 42 middle school students, and 16 high school students, all of whom live in the same residence as their mother tongue. The first language pair that is different from the respondent does not exist. The first language of the spouse's parents is the local language. The language most spoken by respondents is only the local language, and the intensity of leaving the area that speaks other languages is also very rare.

\subsubsection{Respondents' Response Frequency to} Statement Items

a. The Frequency of Respondents 'Responses to the Points of the Statement of' Inheritance among the young Generation

The frequency of respondents' responses to the items of inheritance among the younger generation is that many agree with inheritance among the younger generation. The first question item gets the highest score compared to the other items. The frequency of respondents' responses to the items of inheritance statements among the younger generation with a total score of 365 of the maximum total score is at an index value of 0.91 , which means it is still in the Safe category.

b. Respondents' Response Frequency to Statement Items' Proportion of Muayak Speakers in Population Population '

The frequency of respondents' responses to statement items, the proportion of Muayak speakers in the population is the minority of people who can speak or present Muayak. This response frequency has a score of 282 out of a maximum score of 400 with an index value of 0.70 , which means it is still in the stable category but needs to be treated.

c. Respondents' Response Frequency to the Statement Points' Transition of Muayak Domain '

The frequency of respondents' responses to the Muayak domain transition statement's items is that Muayak can be spoken or displayed in all places and events and can be enjoyed by everyone. The respondent's response frequency is 386 out of 400 and is at an index value of 0.96 , which means it is still in the Safe category.

d. Frequency of Respondents' Responses to Points of Statement on the Change of Wahana Muayak

The frequency of respondents' responses to the Muayak transfer statement points is that Muayak can be displayed in other forms, for example, in the form of compact discs, cassettes, or other audio-visual media. The respondent's response frequency is 395 out of 400 and is in the index value of 0.99 , which means it is still in the Safe category. 
e. Frequency of Respondents' Responses to Points of Muayak Statement in Learning in Schools

The frequency of the respondent's response to the items of the statement muayak in learning at school means the respondents' response to Muayak oral literature to be used as teaching material or local content in schools. The respondent's response frequency is 321 out of a total value of 400 and is at an index value of 0.80 , which means it is still in the stable category but needs to be cared for.

f. The Frequency of Respondents' Responses to the Points of the Government's Attitude Statement on Muayak

The frequency of respondents' responses to the government's attitude towards Muayak is the local government's response to the development of Muayak oral literature in society. What are the preservation efforts, and what has the government done in supporting the preservation and development of regional oral literature, especially Muayak. The respondent's response frequency is 358 out of a total value of 400 and is in the index value of 0.89 , which means it is still in the Safe category.

g. Frequency of Respondents' Responses to Points of Statement of Community Attitudes towards Muayak

The frequency of respondents' responses to the points of the community's attitude towards Muayak is how the community's attitude towards preserving Muayak is one of the region's cultural wealth. The respondent's response frequency is 400 out of 400 and is in the index value of 1.00 , which means it is still in the Safe category.

h. Frequency of Respondents' Responses to Items of Statement of the Amount and Quality of Documentation

The frequency of respondents' responses to the statement items on the number and quality of documentation is the extent to which documentation efforts have been made by the public and the government towards Muayak oral literature. The respondent's response frequency is 383 out of a total value of 400 and is at an index value of 0.98 , which means it is still in the Safe category.

\subsubsection{Vitality of Muayak Oral Literature}

The data processed by SPSS resulted in a total vitality index value of Muayak oral literature of 7.23 and a mean index value of 0.90 . The inheritance index value is in the safe category with a value of 0.91 . While the value of the proportion of Muayak speakers in the population is stable, it needs to be treated with an index value of 0.70 . The transition to the realm of Muayak is in a safe status with an index value of 0.96. the index value for the transfer of Muayak rides is in safe status with a value of 0.99 . The need for Muayak in school learning is stable but needs to be cared for with an index value of 0.80 .

Meanwhile, the government's role is still in a safe status with an index value of 0.89 , which of course, needs to be improved. The community's role remains the most vital thing. This can be seen from the frequency and the highest index value of 1.00 with a safe status. For documentation, it is also safe, with an index value of 0.98 . The following table is the index value per factor and the total vitality index of Muayak oral literature for more details.

Table 1

Index per Factor and Total Inde

\begin{tabular}{|c|c|c|c|}
\hline No. & Indicator & $\begin{array}{l}\text { Values } \\
\text { Index }\end{array}$ & Status \\
\hline 1 & $\begin{array}{l}\text { Inheritance } \\
\text { among young } \\
\text { people }\end{array}$ & 0,91 & Save \\
\hline 2 & $\begin{array}{l}\text { Proportion of } \\
\text { Muayak speakers } \\
\text { in population }\end{array}$ & 0,70 & $\begin{array}{l}\text { Stable but } \\
\text { Need Care }\end{array}$ \\
\hline 3 & $\begin{array}{l}\text { Transition of } \\
\text { Muayak Domain }\end{array}$ & 0,96 & Save \\
\hline 4 & $\begin{array}{l}\text { Muayak Media } \\
\text { Transition }\end{array}$ & 0,99 & Save \\
\hline 5 & $\begin{array}{l}\text { Muayak in school } \\
\text { learning }\end{array}$ & 0,80 & $\begin{array}{l}\text { Stable but } \\
\text { Need Care }\end{array}$ \\
\hline 6 & $\begin{array}{l}\text { The government's } \\
\text { attitude towards } \\
\text { Muayak literature }\end{array}$ & 0,89 & Save \\
\hline 7 & $\begin{array}{l}\text { Public attitude } \\
\text { towards Muayak } \\
\text { literature }\end{array}$ & 1,00 & Save \\
\hline 8 & $\begin{array}{l}\text { Quantity and } \\
\text { quality of } \\
\text { documentation } \\
\end{array}$ & 0,98 & Save \\
\hline \multicolumn{2}{|c|}{ Total } & 7,23 & \\
\hline \multicolumn{2}{|c|}{ Index Average } & 0,90 & Save \\
\hline
\end{tabular}

Based on the above analysis results, it can be seen if the existence and position of Muayak in the Ogan Komering Ulu Selatan community, especially in the research locus area, can still be maintained very well. 
The public and the government can further improve their synergy to introduce Muayak oral literature to the wider community to be known in all districts/cities in South Sumatra or even to the national level.

Muayak is an old type of poetry that has developed in almost all areas of Marga Ranau. Muayak is also one of the oral literature which is still very well preserved in society. This can be seen from the 'presence' of Muayak in traditional activities or other social events such as celebrations, weddings, or other popular entertainment.

Muayak has quite a variety of styles. There are quite striking differences between the styles used by male and female groups. Muayak is an old poem often used to welcome officials who come to the Ogan Komering Ulu Selatan district. Muayak is a tool to convey complaints, criticisms, suggestions, and other interests in a very elegant way. The nature of Wayak, which contains situational poetry, makes this old poem able to "adapt" to the present times.

\section{CONCLUSION}

Based on the results of the analysis that has been carried out on Muayak oral literature in Ogan Komering Ulu Selatan Province, the following conclusions can be drawn:

1. Muayak oral literature is still well preserved by the owner community. This can be seen from the preservation of Muayak oral literature in the community. The community still has the most important role in conservation efforts. As evidenced by the data analysis results, the community role index value is the highest compared to seven other aspects.

2. The role of local government in the conservation of Muayak is also quite good. This can be seen from the index value of 0.89 based on the results of the data analysis. This proves that the government has a significant role in the development and preservation of local oral literature.

3. There is a need for guidance so that Muayak can have better vitality. Learning in the younger generation or being included in the learning system in schools will make the vitality of Muayak even better. This is a separate concern because, based on the analysis results, these two factors need better attention in the future so that the conservation of Muayak can be even better.
4. Muayak is a form of regional oral literature with unique and attractive strengths not only for the people who own it. It will be possible if Muayak can be accepted on the broader community as long as it can be packaged in another form without losing its identity. One of Muayak's strengths is its conditional content. This allows Muayak to be presented in different ways. For example, in terms of delivery or display, it can be made in two languages (regional- Indonesian) to be enjoyed by listeners who do not understand the Komering language.

\section{REFERENCES}

[1] Badan Pengembangan dan Pembinaan Bahasa. (2011). Undang-Undang Republik Indonesia Nomor 24 Tahun 2009 tentang Bendera, Bahasa, dan Lambang Negara, serta Lagu Kebangsaan. Jakarta:Badan Pengembangan dan Pembinaan Bahasa.

[2] Pusat Pengembangan dan Pelindungan, Badan Pengembangan dan Pembinaan Bahasa. (2019). Petunjuk Teknis Pelaksanaan Konservasi Bahasa dan Sastra. Jakarta: Pusat Pengembangan dan Pelindungan.

[3] Tim Redaksi. (2015). Kamus Besar Bahasa Indonesia Edisi Keempat. Jakarta: Gramedia Pustaka Utama.

[4] Pusat Pengembangan dan Pelindungan, Badan Pengembangan dan Pembinaan Bahasa. (2019). Petunjuk Teknis Pelaksanaan Konservasi Bahasa dan Sastra. Jakarta: Pusat Pengembangan dan Pelindungan.

[5] Hutomo, S. S. (1997). Cerita Kentrungan Sarahwulandi Tuban. Jakarta. Pusat Pembinaan dan Pengembangan Bahasa.

[6] Damono, S. D. (2001). "Pengantar" dalam Tradisi Sastra Jawa Radio. Yogyakarta. Kalika.

[7] Zaidan, A. R. (2002). Pedoman Penelitian Sastra Lisan. Jakarta: Pusat Bahasa. https://okuselatankab.go.id/

[8] Pusat Pengembangan dan Pelindungan, Badan Pengembangan dan Pembinaan Bahasa. (2019). Petunjuk Teknis Pelaksanaan Konservasi Bahasa dan Sastra. Jakarta: Pusat Pengembangan dan Pelindungan. 
[9] Riyadi, S. (2008). Pedoman Penyuluhan Sastra Indonesia. Yogyakarta: Balai Bahasa Yogyakarta.

[10] Atmazaki. (1990). Ilmu Sastra Teori dan Terapan. Padang: Angkasa Raya.

[11] Endraswara, S. (2008). Metodologi Penelitian Sastra (Efistemologi, Model, Teori, dan Aplikasi). Yogyakarta: Medpress.

[12] Sudikan, S. Y. (2017). Metode Penelitian Sastra Lisan. Lamongan. CV. Pustaka Ilalang Group.

[13] Susilastri, D. (2019). 'Proposal Penelitian Vitalitas Bahasa dan Sastra Tahun 2019'. Palembang 